\section{Comparative Effects of CPP-ACP and Xylitol F-Varnishes on the Reduction of Tooth Erosion and Its Progression}

\author{
Adilis Alexandria ${ }^{1,2} \mathbb{D}^{-}$, Ana Maria Gondim Valença ${ }^{3}(\mathbb{D}$, Lúcio Mendes \\ Cabral $^{4}{ }^{(10}$, Lucianne Cople Maia ${ }^{1}$ (i)
}

\begin{abstract}
Evaluated the effect of CPP-ACP/NaF and xylitol/ $\mathrm{NaF}$ varnishes in reduce erosion and progression of erosion. Forty enamel blocks were divided into four groups $(n=10): G 1=C P P-$ $\mathrm{ACP} / \mathrm{NaF}$ varnish (MI varnish ${ }^{\mathrm{TM}}$ ); $\mathrm{G} 2=x y$ litol/NaF varnish (Profluorid ${ }^{\circledR}$ ); $\mathrm{G} 3=\mathrm{NaF}$ varnish (Duraphat ${ }^{\circledR}$, positive control) and $\mathrm{G} 4=$ deionized water (Milli0 ${ }^{\circledR}$, negative control). Samples were immersed in Sprite Zero ${ }^{\mathrm{TM}}(\mathrm{pH} 2.58,4 x /$ day, 3 days), in between immersions, the specimens stayed in artificial saliva. After 3 days of erosion, the eroded area was divided in two (half of one received an additional varnish layer while the other half repeated the same 3-day erosion cycle). The 3D, non-contact profilometry technique was used to determinate tooth structure loss (TSL) and surface roughness (SR). Scanning electron microscopy (SEM) and 3D images were utilized to evaluate the topography of the samples. Mann-Whitney, one-way ANOVA and Tukey tests were used (significance level of 0.05\%). SEM and 3D images were descriptively evaluated. After 3 or 6 days of erosion, all tested varnishes were better than G4 $(p<0.05)$ for TSL and SR. In addition, G1 had lower values for TSL than $\mathrm{G} 3(\mathrm{p}<0.05)$ after 3 days of erosion. Under SEM and 3D images observation, all groups presented porosity, irregularities and depressions on the surface enamel after 3 and 6 days of erosion, more pronounced in G4. An application of topical NaF varnishes was effective in reducing TSL and enamel roughness after erosion challenges, being the CCP-ACP/NaF varnish more effective than NaF varnish and water after 3 days of erosion.
\end{abstract}

'Department of Pediatric Dentistry and Orthodontics, School of Dentistry, UFRJ - Universidade Federal do Rio de Janeiro, Rio de Janeiro, RJ, Brazil ${ }^{2}$ Department of Preventive and Community Dentistry, UERJ Universidade do Estado do Rio de Janeiro, Rio de Janeiro, RJ, Brazil ${ }^{3}$ Department of Clinical and Social Dentistry, Dental School, UFPB - Universidade Federal da Paraiba, João Pessoa, PB, Brazil ${ }^{4}$ School of Pharmacy, UFRJ Universidade Federal do Rio de Janeiro Rio de Janeiro, RJ, Brazil

Correspondence: Lucianne C. Maia, Avenida Carlos Chagas Filho 373 Bloco K Sala 01, 21941-971, Rio de Janeiro, RJ, Brasil. Tel: +55-21-39382098. e-mail: orefa@terra.com.br

Key Words: sodium fluoride, tooth erosion, dental enamel.

\section{Introduction}

Nowadays, tooth erosion is widely evident, due an increase in its prevalence, mainly in children and adolescents (1). The chemical wear of dental hard tissue occurs due acids without bacteria involvement (2). Therefore, preventive measures have been suggested to avoid the beginning of the erosion process as well as its progression (3-6).

In dental erosion, the dissolution of mineral from the enamel surface results in a roughened structure (7). With each new erosion process this surface will suffer greatest impact with a fast progression of tissue loss and a visible defect can become apparent (2).

Thus, several methods, such as the use of professional topical fluorides, have been proposed to prevent or slow the progression of dental erosion and its consequences $(3-6,8)$. Recently, other agents, such as casein phosphopeptideamorphous calcium phosphate (CPP-ACP) and xylitol have been studied to protect against erosive wear.

Casein phosphopeptide-amorphous calcium phosphate nanocomplex (CPP-ACP) is a technology based on amorphous calcium phosphate (ACP) and stabilized by casein phosphopeptides (CPP) $(9,10)$. It has been reported that the CPP-ACP nanocomplexes maintain a sufficiently high concentration of calcium and phosphate ions to promote enamel remineralization and interact with fluoride ions to produce an ACFP phase, which gives better benefits because of the fluoride ion (10-12).

Xylitol is a non-acidogenic sweetener very often used in the food industry (13). Due its ability to form complexes with calcium ions $(13,14)$ the addiction of xylitol in dental products can enhance calcium deposition in dental enamel (14) and inhibit the dissolution of calcium and phosphate ions from enamel structure (15). Because of these benefits the addition of CPP-ACP or xylitol in fluoride dental varnishes could have an important influence to reduce dental erosion.

Thus, this in vitro study assessed the effect of CPP$\mathrm{ACP} / \mathrm{NaF}$ and $x y$ litol/ $\mathrm{NaF}$ varnishes in reduce erosion and progression of erosion.

\section{Material and Methods}

\section{Specimen Preparation}

Bovine incisors teeth were cut using an ISOMET lowspeed saw (Buehler Ltd, Lake Bluff, IL, USA) with 2 diamond discs (Extec Corp, Enfield, CT, USA) separated by a 4-mm spacer to obtain the specimens $(4 \times 4 \mathrm{~mm})$ utilized in experiment (Fig. 1A). The block surface was polished using 
water-cooled, silicon carbide paper 600 and 1200 (Extec Corp.), followed by a 1- $\mu \mathrm{m}$ diamond abrasive slurry (Extec Corp.) (Fig. 1B). After each polishing phase, the specimens were cleaned in an ultrasonically device with deionized water (Milli- ${ }^{\circledR}$, Merck KGaA, Darmstadt, Germany) for 5 min (16).

Prior to the experiment, a nail varnish was applied to the left half of the specimen's surface to maintain the sound reference (unexposed area, self-control); the other half of the surface (left side was not covered, exposed area 1) received the treatment and it was exposed to erosion challenges (Fig. 1C).

Baseline surface microhardness (SMH) was measured using a microhardness tester (MICROMET 5104, Buehler, Yokohama, Kanagawa, Japan) with a Knoop diamond under a $50-\mathrm{g}$ load for $5 \mathrm{~s}$, while five indentations spaced $100 \mu \mathrm{m}$ from each other were made at the centre of the enamel surface (Fig. 1D).

A sample size of 10 specimens for each group was calculated by using BioEstat software version 5.3 (Mamirauá Maintainable Development Institute, Belém, PA, Brazil) considering an error level of 5\% and b-error level of 20\%, based on a previous study (12).

Forty enamel specimens $\left(\mathrm{SMH}=369.7 \pm 36.8 \mathrm{~kg} / \mathrm{mm}^{2}\right)$ were randomly allocated to each group: $\mathrm{G} 1=\mathrm{CPP}-\mathrm{ACP} / \mathrm{NaF}$ varnish (2\% CPP-ACP and 5\% NaF, MI varnish ${ }^{\mathrm{TM}}$, GC America, Alsip, Illinois, USA); G2=xylitol/NaF varnish ( $1 \%$ xylitol and $5 \% \mathrm{NaF}_{\text {, Profluorid }}{ }^{\circledR}$, Voco, Cuxhaven, Niedersachsen, Germany); $\mathrm{G} 3=\mathrm{NaF}$ varnish (5\% NaF, Duraphat ${ }^{\circledR}$, Colgate Oral Pharmaceuticals, New York, New York, USA, positive control) and $\mathrm{G} 4=$ deionized water (negative control, Milli- ${ }^{\circledR}{ }^{\circledR}$. The specimens were maintained in $100 \%$ humidity until the beginning of the experiment.

\section{Treatment and Erosive Challenge}

The first treatment was performed at the beginning of the experiment; the varnishes were applied once as a thin layer on the specimen's surface using a microbrush (KG Sorensen, Cotia, SP, Brazil) (Fig. 1E). The specimens were immersed in artificial saliva for 6h (Fig. 1F), after that, the varnish layer was removed using a scalpel blade and acetone with water (1:1), and then the total removal was checked microscopically (40x magnification) (Fig. 1G).

All samples were first subjected to erosion cycles for 3 days; 4 erosion immersions were performed per day for 5 min each, using freshly opened bottles of Sprite Zero ${ }^{\mathrm{TM}}$ (Coca-Cola Company, Porto Real, RJ, Brazil), pH 2.58, $30 \mathrm{~mL} /$ specimen. After each erosion period, samples were rinsed in deionized water. Among the erosive challenge, the samples were immersed in artificial saliva for $2 \mathrm{~h}(1.5 \mathrm{mmol} / \mathrm{L} \mathrm{Ca}$, $0.9 \mathrm{mmol} / \mathrm{LP}, 150 \mathrm{mmol} / \mathrm{L} \mathrm{KCl}, 0.05 \mathrm{mg} \mathrm{F} / \mathrm{mL}$ in $0.1 \mathrm{~mol} / \mathrm{L}$ Tris buffer, $\mathrm{pH}$ 7.0, $30 \mathrm{~mL} / \mathrm{sample}$. After the last day of erosion immersion, the specimens were also stored in artificial saliva overnight. A renewed artificial saliva solution was changed daily in order to avoid oversaturation. The experiment was carried out at $37^{\circ} \mathrm{C}$. The erosive protocol was based on previous study (11).

After 3 days of erosion cycles, the specimens were prepared for a new erosive cycle in which the exposed area (right side of the specimens' surface) was divided into two areas: the 'down' side was protected with a layer of acid-resistant nail varnish (exposed area 1), and the 'up' side of this area received a new treatment (exposed area 2) according to allocation groups (Fig. 11). The specimens were immersed in artificial saliva (Fig. $1 \mathrm{~J}$ ) and after $6 \mathrm{~h}$; the varnish layer was removed (Fig. 1K). After that, the specimens were submitted to a new, 3-day erosion cycle (Fig. 1L).

\section{Enamel Loss Measurement and Roughness Analysis}

A chromatic confocal sensor with a white light axial of 3D, non-contact optical profilometer (Fig. 1M) scanned an area of $1 \times 1 \mathrm{~mm}$ on each specimen (velocity of $2 \mu / \mathrm{s}$ ), which was then analyzed by Nanovea Professional 3D software (Nanovea PS50 Optical, NANOVEA Inc., Irvine, CA, USA) to determine tooth structure loss (TSL) and two parameters of surface roughness: linear roughness (Ra) and area roughness (Sa) accordingly Alexandria et al $(11,12)$.

The 3D non-contact profilometry technique was used to determine the primary outcome: tooth structure loss, i.e., the gap between the experimental and control areas in each group; and the secondary outcomes: surface roughness - linear surface roughness and volumetric surface roughness. All comparisons between the unexposed and exposed areas (exposed Area 1 or exposed Area 2) of enamel were performed after the removal of the acidresistant nail varnish.

The TSL was calculated from the step-height difference between the unexposed and exposed enamel surfaces (exposed Area 1 or exposed Area 2) in each block; three linear measurements were made involving the unexposed and exposed areas. All measurements were done in triplicate, and the mean values were used to represent the final result of the surface profile.

To determine Ra, three linear measurements in each area (unexposed or exposed areas) on the enamel specimen were performed. The average of these three line measurements was used to determine Ra1 (surface linear roughness in unexposed area), Ra2 (surface linear roughness in exposed Area 1) and Ra3 (surface linear roughness in exposed Area 2); the Ra value after 3 days of erosion for all groups was calculated: $R a=R a 2-R a 1$. The Ra value after 6 days of erosion for all groups was calculated: $\mathrm{Ra}=\mathrm{Ra} 3-\mathrm{Ra} 1$.

In the same way, three scanned areas $(200 \mu \mathrm{m} \times 200$ $\mu \mathrm{m})$ were acquired for each block in the unexposed and exposed areas. The average of these three areas was used 
to determine the Sa1 (surface roughness in unexposed area), Sa2 (surface roughness in exposed Area 1) and Sa3 (surface roughness in exposed Area 2); the Sa value after 3 days of erosion for all groups was calculated: $\mathrm{Sa}=\mathrm{Sa} 2$ - Sa1. The Sa value after 6 days of erosion for all groups was calculated: $\mathrm{Sa}=\mathrm{Sa} 3-\mathrm{Sa} 1$.

Scanning Electron Microscopy (SEM) Analysis and 3D Profilometry Images

Three enamel blocks of each group were randomly
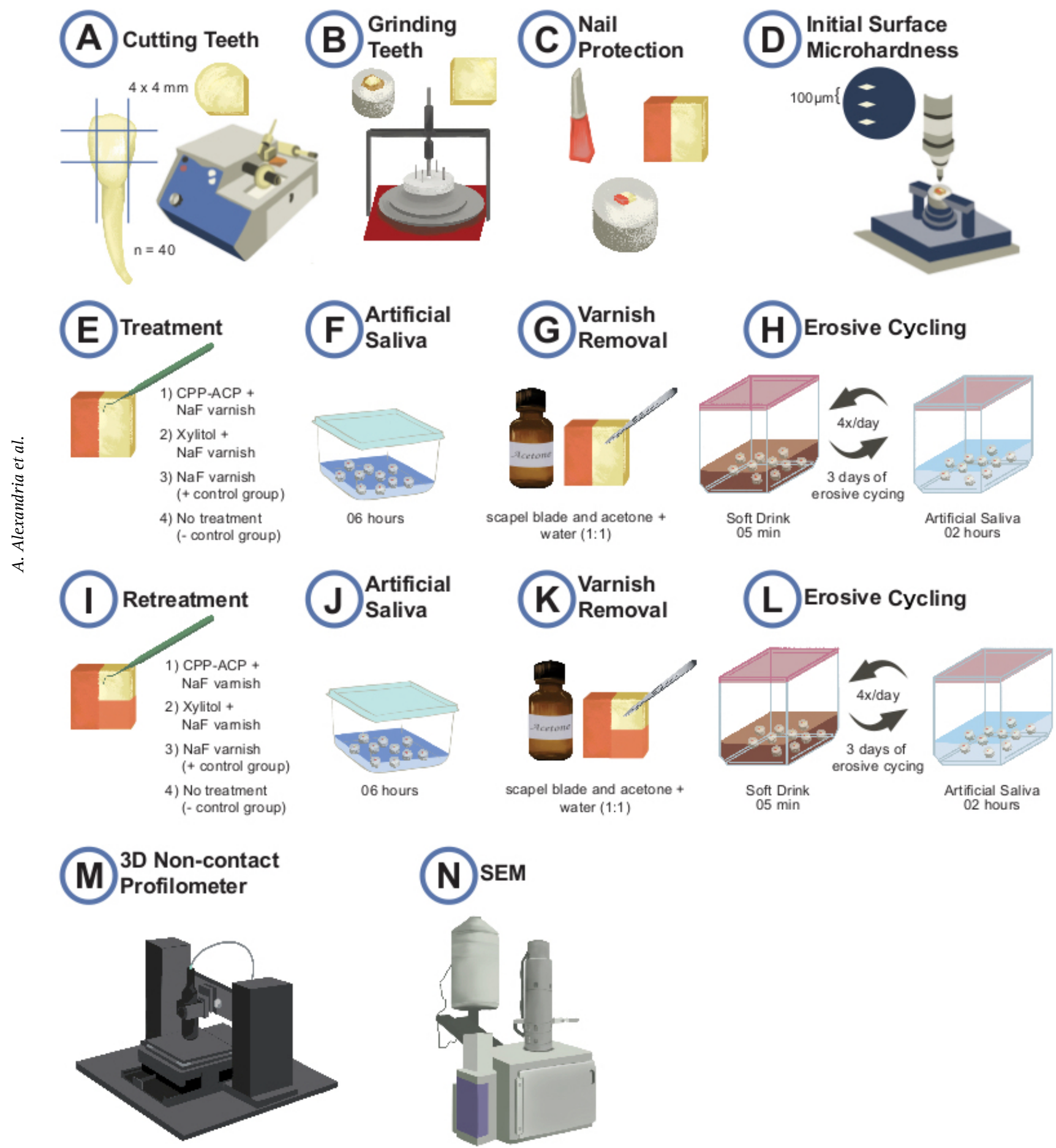

Figure 1. Schematic design of the experimental protocol. A: Cutting teeth, B: Grinding teeth, C: Nail protection of half of specimen, D: Initial surface microhardness, E: Treatment according group, F: Immersion in artificial saliva, G: Varnish treatment removal, H: Erosive Cycling, I: Retreatment according group with nail protection of half of eroded surface, J: Immersion in artificial saliva, K: Varnish treatment removal, L: New erosive cycling, M: 3D Non-contact profilometer and N: SEM analysis 
selected and prepared for SEM analysis with a scanning electron microscope (6460LV, JEOL, Akishima, Tokyo, Japan) (Fig. 1N). The blocks were covered with a 30- $\mu \mathrm{m}$ gold layer and fixed on stubs with double-faced carbon tape. The topography of enamel specimens was analysed in backscattered electrons at $20 \mathrm{kV}$ in low vacuum mode (45Pa). The photomicrographs were acquired under $500 x$ magnification to observe the interface among the three areas (unexposed, exposed Area 1 and exposed Area 2); and $1000 \times$ magnification to observe the changes in detail.

The 3D topographical images (schemes and graphics) were generated from specimens using Nanovea Professional 3D software (Nanovea PS50 Optical, NANOVEA Inc.); one scheme and two graphics were chosen to better represent the results.

\section{Statistical Analysis}

The normal distribution of data was checked for all of the variables tested, using the Shapiro-Wilks test. Differences in the Ra and Sa among treatments were tested using ANOVA following by a Tukey test. Differences in TSL among treatments were tested using a Mann-Whitney test. Comparison between TSL after erosion and TSL after progression inside of treatment groups were made by a paired T-test. SPSS software version 22.0 (IBM, New York, NY, USA) was used for statistical analysis. The significance level was set at 5\%. The photomicrographs acquired in SEM and the 3D schemes and graphics generated by the profilometer were evaluated descriptively.

Table 1. Characteristics of varnishes tested in the study

\begin{tabular}{|c|c|c|c|}
\hline Varnishes & Composition & Manufacturer & $\begin{array}{l}\text { Batch } \\
\text { number }\end{array}$ \\
\hline G1 - MI varnish ${ }^{\mathrm{TM}}$ & $2 \% \mathrm{CPP}-\mathrm{ACP}$ and $5 \% \mathrm{NaF}$ & GC America & 4274 \\
\hline G2 - Profluorid ${ }^{\circledR}$ & $1 \%$ xylitol and $5 \% \mathrm{NaF}$ & Voco & 22112701 \\
\hline G3 - Duraphat ${ }^{\circledR}$ & $5 \% \mathrm{NaF}$ & $\begin{array}{l}\text { Colgate Oral } \\
\text { Pharmaceuticals }\end{array}$ & 116416 \\
\hline
\end{tabular}

\section{Results}

Table 1 summarizes the 3D, non-contact profilometry results for TSL, Ra and Sa after the first erosion (3 days of erosion) and Table 2 show the results for the same parameters after progressive erosion (6 days of erosion).

After 3 days of erosion, all tested varnishes had a protective effect against erosion because all of them statistically differed from the negative control $(p<0.05)$ for TSL. The specimens of $\mathrm{G} 1(6.26 \mu \mathrm{m})$ had statistically lower values for TSL than $\mathrm{G} 4(14.08 \mu \mathrm{m}, \mathrm{p}=0.0001)$ and $\mathrm{G} 3$ $(10.32 \mu \mathrm{m}, \mathrm{p}=0.025)$. The $\mathrm{G} 2(9.89 \mu \mathrm{m})$ did not differ from other varnishes groups $(p=1.000$ and $p=0.149$, for $\mathrm{G} 1$ and $\mathrm{G} 2$, respectively). Though, after re-treatment and another 3 days of erosion (6 days in total) all treatment groups protected against TSL in comparison with the negative control ( $p=0.001$ for $G 1$ and $G 2 ; p=0.004$ for $G 3$ ), showed capacity to protect against the progression of erosion.

The specimens treated with the varnishes (G1, G2 and G3) had lower alterations in topographic roughness ( $\mathrm{Ra}$ and Sa results) than the negative control $(\mathrm{G} 4 ; \mathrm{p}<0.05)$ after 3 or 6 days of erosion. But there was no (statistical) difference among them ( $p>0.05)$.

All groups had a significant increase in surface roughness after 3 days and 6 days of experiment; these results were evident when examining the SEM photomicrographs (Figs. 2 and 3) and 3D topographical images (Fig. 4). The higher differences between unexposed and exposed areas were observed for $\mathrm{G} 4$, this result was more expressive than in other groups, and the small differences were seen for $\mathrm{G} 1$ (Figs. 2 and 4). In $\mathrm{G} 2$ and $\mathrm{G} 3$, there was a similarity of erosion patterns with irregularities, exposure of enamel prisms, and depressions on surface enamel after 3 and 6 days of erosion; in $\mathrm{G} 1$, it was possible to observe only the exposure of enamel prisms that was more pronounced after 6 days of erosion. In exposed areas of $\mathrm{G} 4$ we observed the greatest alterations in enamel topography with extensive depressions, craters

Table 2. 3D non-contact profilometry results: median $(\mathrm{min} / \mathrm{max})$ of tooth structure loss (TSL) and mean \pm SD of surface roughness (Ra and Sa) of enamel specimen groups after erosion challenge ( 3 and 6 days of erosion)

\begin{tabular}{cccccccc}
\hline & \multicolumn{2}{c}{ After 3 days of erosion } & & \multicolumn{3}{c}{ After 6 days of erosion } \\
\hline Groups & \multicolumn{2}{c}{ TSL } & Ra & Sa & TSL & Ra & Sa \\
G1 (MI varnish ${ }^{\mathrm{TM}}$ ) & $6.26(4.05 / 9.28)^{\mathrm{A}, \mathrm{b}}$ & $0.38 \pm 0.13^{\mathrm{a}}$ & $0.27 \pm 0.04^{\mathrm{a}}$ & $10.88(8.20 / 19.61)^{\mathrm{B}, \mathrm{a}}$ & $0.51 \pm 0.08^{\mathrm{a}}$ & $0.36 \pm 0.12^{\mathrm{a}}$ \\
G2 (Profluorid $\left.{ }^{\circledR}\right)$ & $9.89(8.14 / 13.72)^{\mathrm{A}, \mathrm{a}, \mathrm{b}}$ & $0.43 \pm 0.19^{\mathrm{a}}$ & $0.32 \pm 0.15^{\mathrm{a}}$ & $10.57(6.20 / 13.92)^{\mathrm{B}, \mathrm{a}}$ & $0.54 \pm 0.12^{\mathrm{a}}$ & $0.44 \pm 0.20^{\mathrm{a}}$ \\
G3 (Duraphat $\left.{ }^{\circledR}\right)$ & $10.32(17.24 / 9.50)^{\mathrm{A}, \mathrm{a}}$ & $0.45 \pm 0.12^{\mathrm{a}}$ & $0.28 \pm 0.14^{\mathrm{a}}$ & $12.54(10.25 / 16.19)^{\mathrm{A}, \mathrm{a}}$ & $0.50 \pm 0.11^{\mathrm{a}}$ & $0.42 \pm 0.10^{\mathrm{a}}$ \\
G4 (deionized water) & $14.06(26.80 / 10.61)^{\mathrm{A}, \mathrm{c}}$ & $1.02 \pm 0.22^{\mathrm{b}}$ & $0.85 \pm 0.17^{\mathrm{b}}$ & $19.42(13.82 / 26.80)^{\mathrm{B}, \mathrm{b}}$ & $1.25 \pm 0.30^{\mathrm{b}}$ & $1.14 \pm 0.41^{\mathrm{b}}$ \\
\hline
\end{tabular}

Medians and means followed by distinct letters are statistically different $(\mathrm{p}<0.05)$. Capital letters show difference between TSL after erosion $(3$ days of erosion) and TSL after progression of erosion (6 days of erosion) inside each group (paired T-test) and lower case letters in the same column show differences among treatments (Mann-Whitney test for TSL and ANOVA followed by Tukey test for Ra and Sa). 
and exposure of enamel prisms (Fig. 3).

\section{Discussion}

Investigations of products that could promote reduce of dental erosion and its progression is very important to minimize the consequences to the oral cavity (3). Dental erosion causes a chemical wear of dental hard tissue (2), and it is an increasing problem in the world (1). Products with high concentration of fluoride, adherence to teeth and slow release, like varnishes, could be seen as potential products to be used in a clinical practice to promote protection against dental erosion $(4,5)$.

Varnish is easy to apply, safe and well tolerated by babies; young children and individuals who require assistance for disabilities, besides, the formation of a mechanical barrier, in comparison with other fluoride vehicles (17). In the present study, the varnishes had the same fluoride concentration, were applied only once and completely removed after $6 \mathrm{~h}$
$(11,12,17,18)$ in order to simulate the clinical situation, which the varnishes might be removed through tooth brushing and chewing, focusing on the chemical effect rather than on the mechanical protection.

This is the first study to assess the effect of varnishes containing fluoride with or without calcium or xylitol to reduce enamel erosion and progression of erosion. Although the CPP-ACP and Xylitol products have being related to de-remineralization process, little is known about the antierosive effect of CPP-ACP or Xylitol varnishes.

Considering the results of the present study, CPP-ACP/ $\mathrm{NaF}, \mathrm{Xylitol} / \mathrm{NaF}$ and $\mathrm{NaF}$ varnishes were able to reduce alterations in roughness and tooth structure loss after 3 days of erosion challenge. In addition, CPP-ACP/NaF presents better effect in reducing the TSL depth than NaF varnish and water. The present authors believe that the presence of calcium and phosphate in the CPP-ACP/NaF

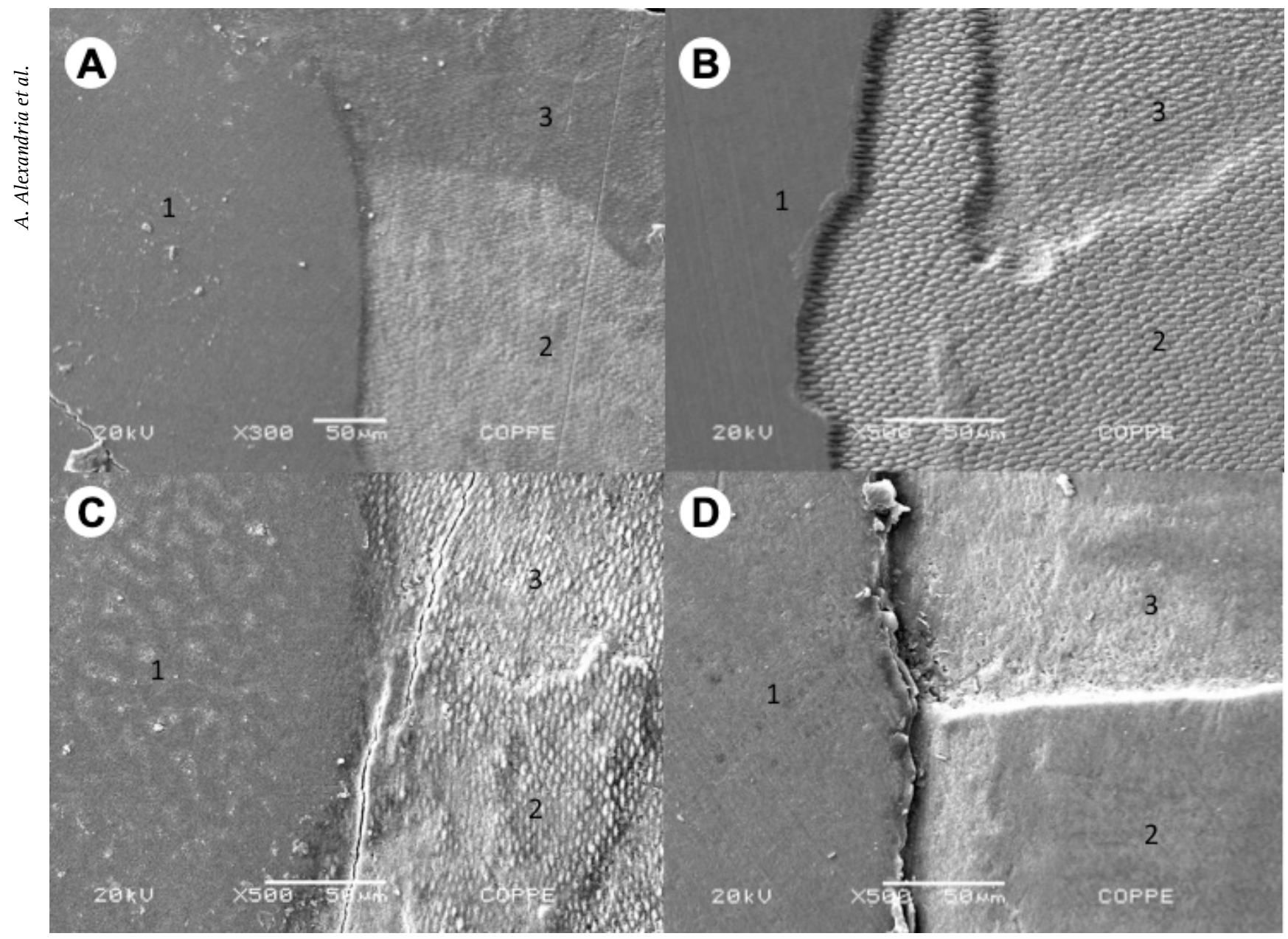

Figure 2. Surface SEM photomicrographs of enamel samples after treatment and erosion challenge at 500 $\times$ magnification. A: G1=CPP-ACP + $\mathrm{NaF}$ (MI varnish ${ }^{\mathrm{TM}}$ ), B: G2=xylitol $+\mathrm{NaF}$ (Profluorid $\left.{ }^{\circledR}\right), \mathrm{C}$ : G3=NaF varnish (Duraphat ${ }^{\circledR}$, positive control) and D: G4=Deionized water (negative control). Area 1 = the unexposed area (sound enamel), Area $2=$ exposed area 1 (after 3 days of erosion) and Area $3=$ exposed Area 2 (after 6 days of erosion and progression of erosion). 
varnish support the highest reduction of roughness and TSL, independently of the fluoride concentration present in experimental products $(9,10)$.

After 6 days of erosion, there was an increase in TSL

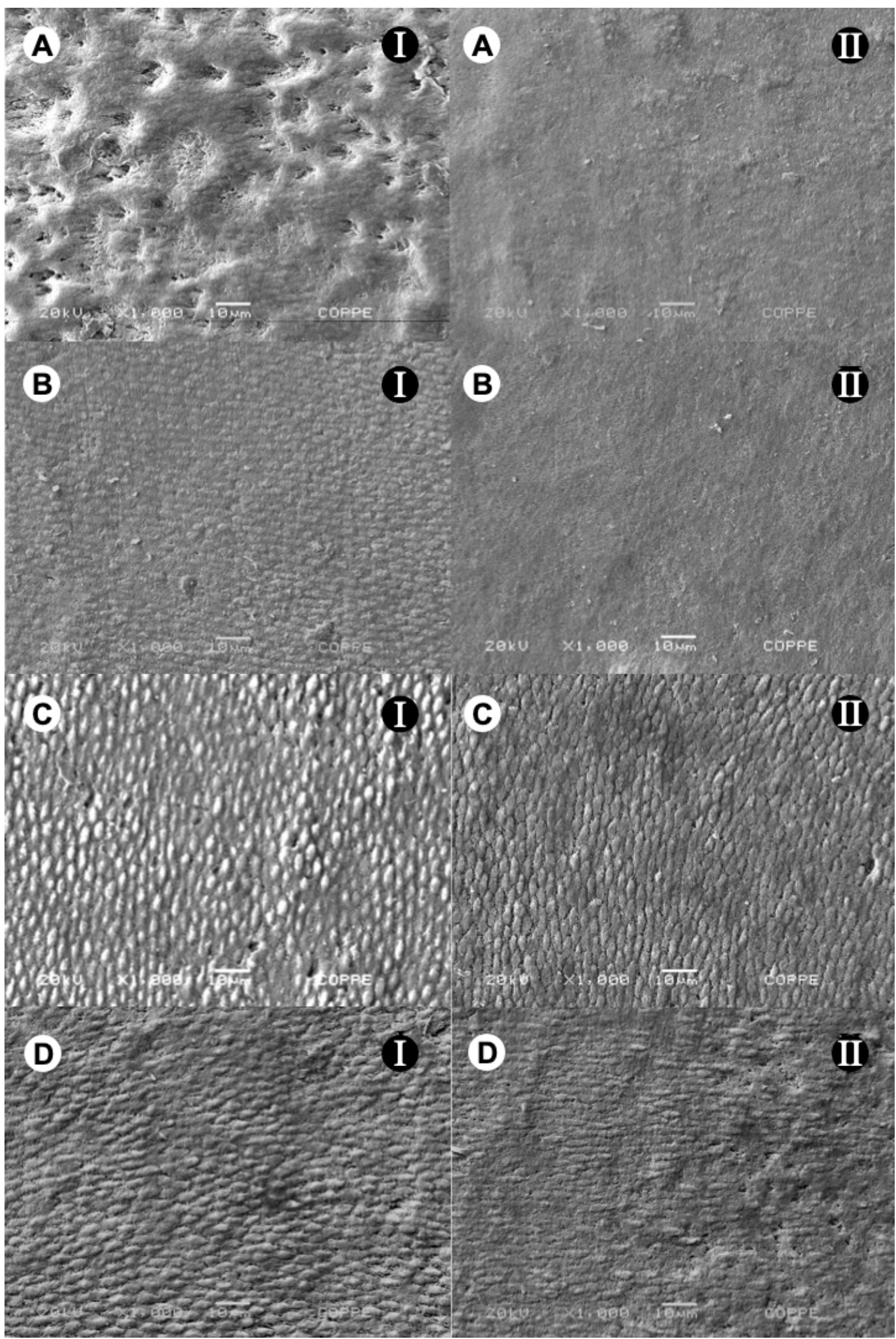

Figure 3. Surface SEM photomicrographs of enamel samples after treatment and erosion challenge at 1000× magnification. A: G1=CPP-ACP + $\mathrm{NaF}$ (MI varnish ${ }^{\mathrm{TM}}$ ), (B) G2=xylitol + NaF (Profluorid ${ }^{\circledR}$ ), (C) G3=NaF varnish (Duraphat ${ }^{\circledR}$, positive control) and (D) G4=deionized water (negative control). Photomicrographs I=exposed Area 1 (after 3 days of erosion) and Photomicrographs II=exposed Area 2 (after 6 days of erosion and progression of erosion). 
values, all tested varnishes had the same capacity to reduce the progression of erosion, and no differences were observed between varnishes results to roughness and TSL. With the higher erosive challenge, the CPP-ACP/NaF varnish was not superior to minimize mineral loss. The beneficial action of calcium and phosphate observed on sound enamel was not similar in eroded enamel, it is speculated that the structural alteration in previously eroded enamel may interfere with the incorporation of calcium and phosphate in remineralization process.

When comparing the SEM photomicrographs and 3D images, the enamel surface of specimens treated with CPP-ACP/NaF varnish showed slight superficial erosion, xylitol/NaF and $\mathrm{NaF}$ groups shows some superficial irregularities, exposure of enamel prisms and depressions more pronounced than in $\mathrm{CPP}-\mathrm{ACP} / \mathrm{NaF}$ group, but the greater differences between unexposed and exposed areas were observed for negative control, that showed a destructive aspect, including evident irregularities and porosities, independently of the days of erosion.

The literature explains the optimistic results of fluoride varnishes, in general, because this chemical effect with the formation of a protective globules of $\mathrm{CaF}_{2}$-like on dental tissue $(6,7)$. These globules can participates in the de-remineralisation process; with inhibition of the demineralisation plus precipitation of fluor(hydroxy) apatite, but also act as a physical block reducing the contact of erosive acid with the dental enamel $(7,8)$.

The potential of conventional $\mathrm{NaF}$ varnish to prevent the erosive process has been reported in the literature $(18,19)$. The NaF varnish demonstrated the same capacity to reduce roughness and TSL after 3 or 6 -days of erosion, and after a great erosive challenge (6 days), the effect of $\mathrm{NaF}$ varnish became more evident. The mineral loss after an erosive challenge exposes more internal layers of the enamel (11) and increased roughness that promotes a larger
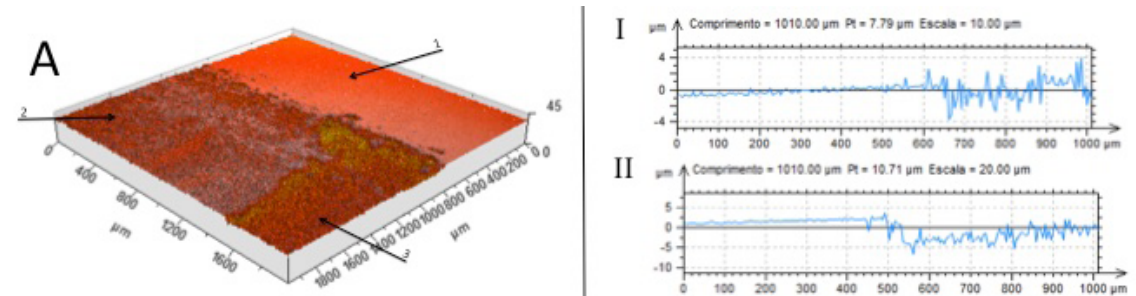

II
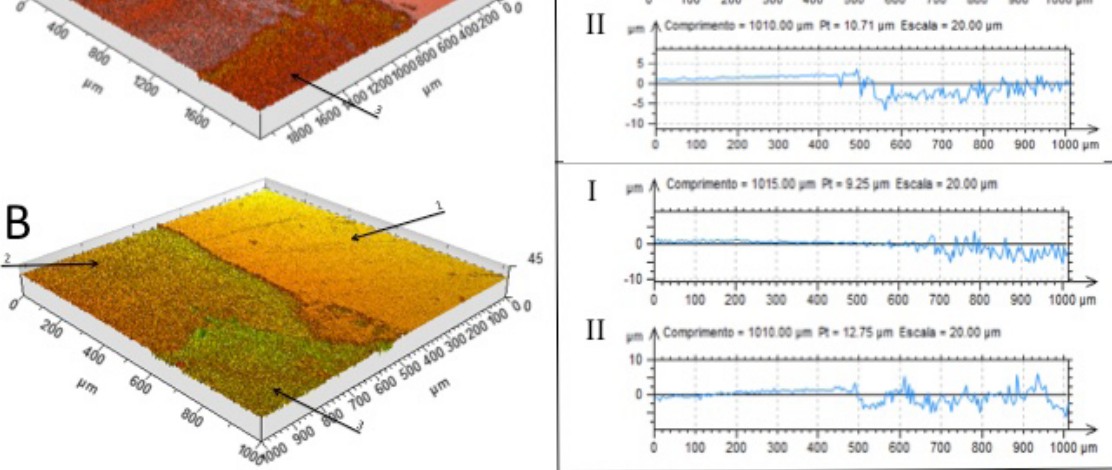

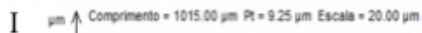

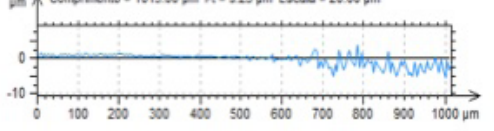

II
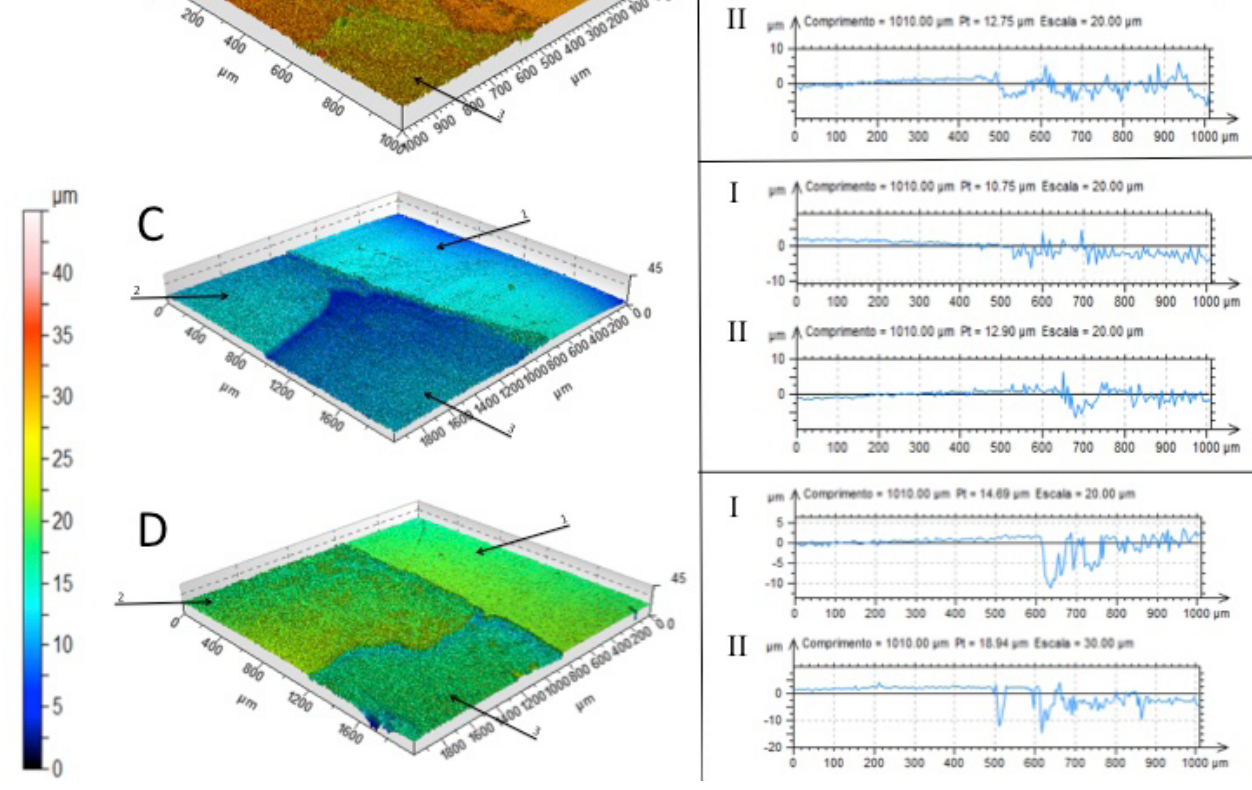

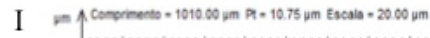

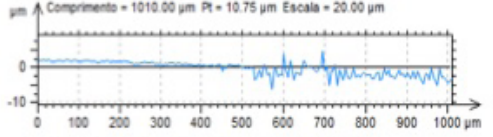

II
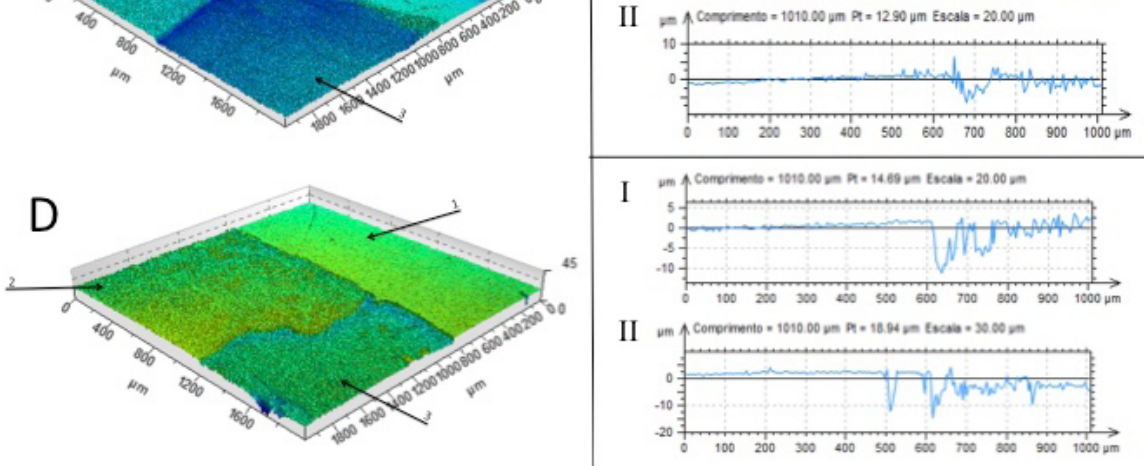

Figure 4. 3D profilometry scheme and graphic representation of enamel surface samples after treatment and erosion challenge (after 3 and 6 days of erosion) for each group. (A) G1=CPP-ACP + NaF (MI varnishTM), (B) G2=xylitol + NaF (Profluorid ${ }^{\circledR}$ ), (C) G3=NaF varnish (Duraphat ${ }^{\circledR}$, positive control) and (D) G4=deionized water (negative control). Arrow $1=$ the unexposed area (sound enamel), Arrow $2=$ exposed Area 1 (after 3 days of erosion) and Arrow 3 = exposed Area 2 (after 6 days of erosion and progression of erosion). Graphic $I=$ profile of unexposed area to exposed Area 1, Graphic II = profile of unexposed area to exposed Area 2. 
surface area for chemical bonds to occur (8). Probably, the formation of $\mathrm{CaF}_{2}$ globules on a previously eroded surface was greater.

The bioavailability of calcium and phosphate ions present in CPP-ACP nanocomplexes products can explain the good results of CPP-ACP/NaF varnish $(9,10)$. The penetration of calcium and phosphate in enamel could cause the supersaturation of ions allowing the reduction of structural loss (20). In addition, the casein can modify some mechanical properties of enamel, making it less susceptible to mineral loss (9). Although this mechanism in remineralization process is recognized, eroded enamel may respond differently. Depending on the porosity of the enamel after erosion, a further exposure to calcium ad phosphate compounds may generate mineral deposits only on the surface of the erosive lesion, which would explain the results of CPP-ACP varnish in the face of a new erosive challenge (2). In addition, it is possible that higher phosphate levels may require stabilizing calcium in situations of an eroded enamel structure $(2,21)$.

Agreeing with the results of present study, Alexandria et al. (18) observed a reduced of roughness and TSL by CPP-ACP/NaF varnish after erosion challenge. Wang et al. (20) and Other studies with CPP-ACP products show good results in favour of CPP-ACP products $(11,18,20)$, independent of the vehicle utilized.

The mechanism of action of xylitol on enamel remineralization is still uncertainty, but previous studies $(13,14)$ reports that xylitol products could decrease the dissolution of calcium and phosphate ions of tooth, reducing the mineral loss. It might be speculated that the xylitol can act as a calcium ion transporter due its ability to form calcium complexes with saliva that facilitates bioavailability of calcium ions (11). The xylitol/NaF vanish had a good performance regardless of the erosive challenge, being similar to both $\mathrm{NaF}$ and $\mathrm{CPP}-\mathrm{ACP} / \mathrm{NaF}$ varnishes. In researched literature, we did not find studies that evaluated the action of xylitol/NaF varnish in dental erosion.

Rochel et al. (22) showed that a fluoridated xylitol dentifrice was able to protect enamel against erosion with or without abrasion. Vongsavan et al. (15) observed in vitro that fluoride xylitol products was able to reduce the tooth demineralization, but no better than fluoride product alone. Souza et al. (19) observed that $\mathrm{NaF}$ varnish and $10 \%$ or $20 \%$ xylitol vanishes were able to reduce erosion ( 5 days challenge), however only xylitol varnishes were capable to decrease the progression of erosion after 10 days of erosion. Cardoso et al. (23) observed that 20\% xylitol varnish increase remineralization of enamel in situ.

The application of topical fluoride varnishes was effective in reducing erosion or progression of erosion. Additionally, the CPP-ACP/NaF varnish was more effective in reducing tooth structure loss than $\mathrm{NaF}$ varnish and water after 3 days of erosion. Nevertheless, in view of the conflicting results in literature concerning prevention of dental erosion and few studies testing the action of CPP-ACP/NaF and xylitol/NaF varnishes against erosion challenge, we emphasize that these findings provided a basis for future in situ studies and clinical trials that will determine the effect of these varnishes in reducing clinical erosive tooth wear.

\section{Resumo}

Avaliou-se o efeito dos vernizes $\mathrm{CPP}-\mathrm{ACP} / \mathrm{NaF}$ e xilitol/ $\mathrm{NaF}$ na redução da erosão e progressão da erosão. Quarenta blocos de esmalte foram divididos em quatro grupos ( $\mathrm{n}=10)$ : $\mathrm{G} 1=$ verniz CPP-ACP/NaF (verniz MI ${ }^{\mathrm{TM}}$ ); $\mathrm{G} 2=$ verniz $x$ ilitol/NaF $\left(\right.$ Profluorid $^{\circledR}$ ); G3 $=$ verniz NaF (Duraphat ${ }^{\circledR}$, controle positivo) e $\mathrm{G} 4=a$ gua desionizada (MilliQ ${ }^{\circledR}$, controle negativo). As amostras foram imersas em refrigerante Sprite Zero ${ }^{\mathrm{TM}}(\mathrm{pH} 2.58,4 x / \mathrm{dia}, 3$ dias), entre imersões, os espécimes ficaram em saliva artificial. Após 3 dias de erosão, a área erodida foi dividida em duas (metade recebeu uma camada adicional de verniz, enquanto a outra metade repetiu o mesmo ciclo de erosão de 3 dias). A técnica de perfilometria 3D de não contato foi utilizada para determinar a perda de estrutura dentária (PED) e rugosidade superficial (RS). Microscopia eletrônica de varredura (MEV) e imagens em 3D foram utilizadas para avaliar a topografia das amostras. Testes de Mann-Whitney, One-way ANOVA e Tukey foram utilizados (nivel de significância de $0,05 \%$ ). Imagens do MEV e 3D foram avaliadas descritivamente. Após 3 ou 6 dias de erosão, todos os vernizes testados foram melhores que G4 $(p<0,05)$ para PED e RS. Além disso, o $\mathrm{G} 1$ apresentou menores valores de PED do que o $\mathrm{G} 3(\mathrm{p}<0,05)$ após 3 dias de erosão. Observando as imagens em MEV e 3D, todos os grupos apresentaram porosidade, irregularidades e depressões no esmalte superficial após 3 e 6 dias de erosão, sendo mais pronunciados no G4. Uma aplicação tópica de vernizes fluoretados foi eficaz na redução da rugosidade e PED do esmalte após desafios de erosão. Além disso, o grupo CPP-ACP/NaF teve melhor desempenho na redução da PED quando comparado ao verniz de $\mathrm{NaF}$ e a água, após 3 dias de erosão.

\section{Acknowledgements}

The authors acknowledge the financial support from CAPES, FAPERJ (E-26/201.316/2014) and CNPQ (302800/2012-3, and 152231/2016-1). This study is part of the PhD thesis of the first author. The authors thank Amanda Garcia Mayworm and Rafael Lopes Marambaia for their support during these experiments.

\section{References}

1. Salas MM, Nascimento GG, Huysmans MC, Demarco FF. Estimated prevalence of erosive tooth wear in permanent teeth of children and adolescents: an epidemiological systematic review and meta-regression analysis. J Dent 2015;43:42-50.

2. Neel EAA, Aljabo A, Strange A, Ibrahim S, Coathu M, Young AM, et al. Demineralization-remineralization dynamics in teeth and bone. Int J Nanomedicine 2016;11:4743-4763.

3. Lussi A, Carvalho TS. The future of fluorides and other protective agents in erosion prevention. Caries Res 2015;49:18-29.

4. Sar Sancakli H, Austin RS, Al-Saqabi F, Moazzez R, Bartlett D. The influence of varnish and high fluoride on erosion and abrasion in a laboratory investigation. Aust Dent J 2015;60:38-42.

5. Lippert F. Fluoride release from fluoride varnishes under acidic conditions. J Clin Pediatr Dent 2014;39:35-39.

6. Cochrane NJ, Shen P, Yuan Y, Reynolds EC. Ion release from calcium and fluoride containing dental varnishes. Aust Dent J 2014;59:100-105.

7. Ganss C, Lussi A, Schlueter N. The histological features and physical properties of eroded dental hard tissues. Monogr Oral Sci 2014;25:99- 
107.

8. Huysmans MC, Young A, Ganss $C$. The role of fluoride in erosion therapy. Monogr Oral Sci 2014;25:230-243.

9. Ekambaram M, Mohd Said SNB, Yiu CKY. A Review of enamel remineralisation potential of calcium- and phosphate-based remineralisation systems. Oral Health Prev Dent 2017;15:415-420.

10. Tao $S$, Zhu Y, Yuan H, Tao S, Cheng Y, Li J, et al. Efficacy of fluorides and CPP-ACP vs fluorides monotherapy on early caries lesions: A systematic review and meta-analysis. PLoS One 2018;13:e0196660.

11. Alexandria AK, Vieira TI, Pithon MM, da Silva Fidalgo TK, FonsecaGoncalves A, Valenca AM, et al. In vitro enamel erosion and abrasioninhibiting effect of different fluoride varnishes. Arch Oral Biol 2017;77:39-43.

12. Alexandria AK, Meckelburg NA, Puetter UT, Salles JT, Souza IPR, Maia LC. Do pediatric medicines induce topographic changes in dental enamel? Braz Oral Res 2016;30:1-8.

13. Makinen KK. Sugar alcohols, caries incidence, and remineralization of caries lesions: a literature review. Int J Dent 2010:981072.

14. Miake Y, Saeki Y, Takahashi M, Yanagisawa T. Remineralization effects of xylitol on demineralized enamel. J Electron Microsc 2003;52:471476.

15. Vongsavan K, Surarit R, Rirattanapong P. The combined effect of xylitol and fluoride in varnish on bovine teeth surface microhardness. Southeast Asian J Trop Med Public Health 2014;45:505-510.

16. Nassur C, Alexandria AK, Pomarico L, de Sousa VP, Cabral LM, Maia LC. Characterization of a new $\operatorname{TiF}(4)$ and beta-cyclodextrin inclusion complex and its in vitro evaluation on inhibiting enamel demineralization. Arch Oral Biol 2013;58:239-247.

17. Levy FM, Magalhaes AC, Gomes MF, Comar LP, Rios D, Buzalaf MA. The erosion and abrasion-inhibiting effect of TiF(4) and $\mathrm{NaF}$ varnishes and solutions on enamel in vitro. Int J Paediatr Dent 2012;22:11-16.

18. Alexandria AK, Valenca AMG, Cabral LM, Maia LC. Fluoride varnishes against dental erosion caused by soft drink combined with pediatric liquid medicine. Braz Dent J 2017;28:482-488.

19. Souza JG, Rochel ID, Pereira AF, Silva TC, Rios D, Machado MA, et al. Effects of experimental xylitol varnishes and solutions on bovine enamel erosion in vitro. J Oral Sci 2010;52:553-559.

20. Wang CP, Huang SB, Liu Y, Li JY, Yu HY. The CPP-ACP relieved enamel erosion from a carbonated soft beverage: an in vitro AFM and XRD study. Arch Oral Biol 2014;59:277-282.

21. Karlinsey RL, Mackey AC, Blanken DD, Schwandt CS. Remineralization of eroded enamel lesions by simulated saliva in vitro. Open Dent $J$ 2012;6:170-176

22. Rochel ID, Souza JG, Silva TC, Pereira AF, Rios D, Buzalaf MA, et al. Effect of experimental xylitol and fluoride-containing dentifrices on enamel erosion with or without abrasion in vitro. J Oral Sci 2011;53:163-168.

23. Cardoso CA, Cassiano LP, Costa EN, Souza ESCM, Magalhaes AC, Grizzo LT, et al. Effect of xylitol varnishes on remineralization of artificial enamel caries lesions in situ. J Dent 2016;50:74-78.

Received January 4, 2020

Accepted March 9, 2020 